\title{
BrisSynBio Art-Science Dossier
}

\author{
Maria Fannin (1) - Katy Connor (D) - David Roden • \\ Darian Meacham (iD
}

Received: 29 March 2020 / Accepted: 3 April 2020 / Published online: 12 May 2020

(C) The Author(s) 2020

\begin{abstract}
Finding avenues for collaboration and engagement between the arts and the sciences (natural and social) was a central theme of investigation for the Responsible Research and Innovation (RRI) and Public Engagement programme at BrisSynBio, a BBSRC/ EPSRC Synthetic Biology Research Centre that is now part of the Bristol BioDesign Institute at University of Bristol (UK). The reflections and experiments that appear in this dossier are a sample of these investigations and are contributed by Maria Fannin, Katy Connor and David Roden. Darian Meacham coordinated and introduces the dossier.
\end{abstract}

Keywords Art-science collaboration · Public engagement · Responsible research and innovation . Synthetic biology $\cdot$ Technology Interdisciplinary research

\footnotetext{
M. Fannin

School of Geographical Sciences, Universityof Bristol, University Road, Clifton, Bristol BS8 1SS, UK

\section{K. Connor}

Visual Artist and Creative Producer, Spike Island, 133

Cumberland Road, Bristol BS1 6UX, UK

URL: https://www.katyconnor.net/

D. Roden

Department of Philosophy, Faculty of Arts and Social Sciences, The Open University, Walton Hall, Milton Keynes MK7 6AA, UK

\section{Meacham $(\bowtie)$}

Department of Philosophy, Maastricht University, 90-92 Grote Gracht, 6211 SZ NL \& BrisSynBio, Life Sciences Building, Tyndall Avenue, Bristol BS8 1TQ, UK e-mail: d.meacham@maastrichtuniversity.nl
}

\section{Introduction (by Darian Meacham)}

Finding avenues for collaboration and engagement between the arts and the sciences (natural and social) was a central theme of investigation for the Responsible Research and Innovation (RRI) and Public Engagement programme ${ }^{1}$ at BrisSynBio, a BBSRC/EPSRC Synthetic Biology Research Centre that is now part of the Bristol BioDesign Institute at the University of Bristol (UK). The reflections and experiments that appear in this dossier are a small sample of these investigations. From the Centre's inception in 2013, the thinking was that engagement with the arts would be a stimulant for discussion and mutual learning with various publics, practitioners and researchers from various disciplines and that it would allow researchers within synthetic biology, and more specifically BrisSynBio itself, to rethink or reimagine questions and ways of asking questions about the scientific and socio-economic enterprise that they were engaged in. These included questions about how that enterprise appeared to those outside of its day-to-day activities as well as how the encounter with questions about aesthetic judgement and artistic practices could transform how the enterprise appeared to the researchers working within it; and also how this activity of reimagining through engagement with aesthetic questions might help to build understanding and communication across communities concerning some of the

\footnotetext{
${ }^{1}$ A timeline from 2015 to 2018 of public engagement activities at BrisSynBio is available at http://www.bristol.ac.uk/medialibrary/sites/brissynbio/documents/Public\%20Engagement $\% 20$ Timeline.pdf (last accessed 31 March 2020)
} 
ethical, social, economic and political questions swirling around the Centre and synthetic biology more broadly. Modestly speaking, such engagements could be considered as an attempt at some modicum of greater inclusivity in the public sphere of the republic of science; an acknowledgement of Sheila Jasanoff's assertion that "the $20^{\text {th }}$ century's greatest breakthroughs in the sciences have made it increasingly more acceptable for biologists to claim ownership of the meaning of life $[\ldots]$ the origins and implications of that growing primacy deserve our attention" [1]. The theme of art-science collaborations as the basis for "deliberative discussions on research agendas and direction" is taken up by Michael Reinsborough [2] in this issue. A broader analysis of the responsible innovation and public engagement programme at BrisSynBio can be found in Pansera et al. [3].

Attempts at mutual-learning through aesthetic engagement came quite naturally - so to speak - to the Centre. This was due to several factors. First, synthetic biology, a field born of knowledge and material coproduction between biology, chemistry, engineering and computer science, has constant translation between disciplines built into it. The attempts at translation and its failure that are part and parcel of aesthetic engagement with the natural and social sciences are also integral to synthetic biology itself. Second, as Massimiliano Simons [4] points out, the history of engineering is replete with the self-understanding of engineers as close to the arts and enacting the character of Metis, goddess of magical cunning, who somehow tricks nature, hence the affinity between synthetic biology and design thinking (e.g. protein design). Third, the Centre for Public Engagement at University of Bristol was a partner in BrisSynBio. This added not only a great depth of experience in public engagement activities and methodologies to the Centre's expertise but also opened possibilities for local and international collaborations, including through European Framework Programme projects, e.g. SYNENERGENE. ${ }^{2}$ A fourth factor is offered by the city of Bristol itself, with its vibrant arts and music scene. As expressed in its

\footnotetext{
${ }^{2}$ SYNENERGENE was a 4-year mobilization and mutual learning action plan (MMLAP) supported by the European Commission under the 7th Framework Programme. The project aimed at initiating and fostering public dialogue on synthetic biology and mutual learning processes among a wide variety of stakeholders from science, industry, civil society, education, art and other fields.
}

logo, designed by a local artist, BrisSynBio saw itself as embedded in the city and its artistic/design traditions (Fig. 1).

Thus, the impetus for engagement with the city's artists as a form of public and deliberative engagement was understood as part of the civic mission and role of the Centre.

The three pieces that make up this dossier form a constellation around the project "Blood Culture: reimag(in)ing life at a cellular scale":

[Blood Culture: reimag(in)ing life at a cellular scale] explores how artistic research as methodology can bring new insights to the lab-based practices of cell culture and in particular to the practices of culturing red blood cells. It will bring together biochemist Ash Toye from the Bristol Synthetic Biology Research Centre (UoB, BrisSynBio) and researchers in his laboratory; artistic researcher Katy Connor, interested in exploring the boundaries between bodies and technologies; and two social scientists, Maria Fannin (UoB, Geographical Sciences) and Julie Kent (UWE, Bristol/BrisSynBio); to explore how shared interests in blood culture technologies can contribute new conceptual vocabularies and practical insights into Art-Science collaboration. It will therefore enable new perceptual encounters to occur between the four participants: asking how researchers and artists work with 'lively' materials like cultured human tissue; exploring novel ways of articulating the cultural, ethical and aesthetic practices involved in culturing blood; and inherent

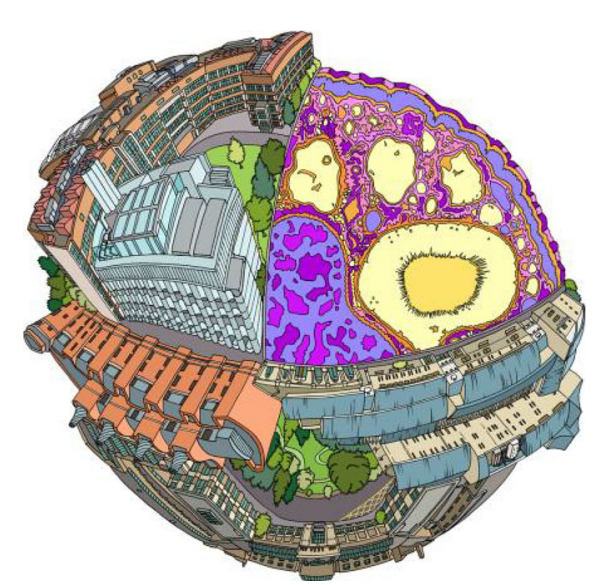

Fig. 1 BrisSynBio logo by Andy Council 
reflections on methodological approaches to 'making'.

Maria Fannin's contribution to this dossier is a reflection on the collaboration and the questions and challenges it presented as emblematic of cross-disciplinary collaboration in synthetic biology, specifically those collaborations involving social scientists, researchers from the humanities and artists. Connor's piece offers an account of and reflection on the Blood Culture Project. She "argue [s] that the consideration of human bio-matter as an art medium, opens up an intriguing cultural space to critically reflect upon relationships between biology and technology, materiality and ethics, as well as the production of new cultural meanings through metaphor". Finally, Bristol-based philosopher David Roden uses the encounter with Connor's work as a catalyst for experimental speculative reflections on synthetic biology, technology and art that sit at the edge of theory fiction.

\section{Red Blood Cell Cultures: Reflections on Art/Social Science/Science Collaboration (by Maria Fannin)}

Collaboration across disciplines is always challenging. Researchers and practitioners may have common interests but draw on entirely different epistemological positions, vocabularies and norms in their own sites of practice. Presumptions made in one discipline may be the subject of sustained and critical reflection in another. Indeed, some disciplines are themselves marked by divisions between science and social science or between science and the humanities. As a geographer whose training included deep engagement with cultural studies as well as traditional social science methods (including, like many other human geographers, digital cartography and statistical methods), these divisions are familiar. Like all demarcations of (disciplinary) territories, however, critical geographical work tells us that these boundaries and divisions are not natural or unchanging but are constructed and performed in daily practice and shaped by disciplinary norms and expectations. Enthusiasm for another's work can also go a long way to making the constructed and normative dimensions of disciplinary boundaries more visible and for helping initiate conversations that explore the fluidity and mutability of these boundaries and where collaborators

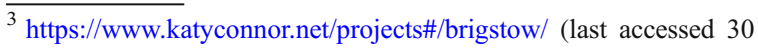
March 2020)
}

might, ideally, generate a new context and horizon for working together that is more than simply the sum of all their disciplinary parts.

Multiple disciplines are now being brought together around scientific research in synthetic biology. The art/ science/social science boundary is one that has gained recognition and critical reflection as artists seek to work with the materials and methods of scientific research. Likewise, scientific researchers seek new ways of imagining and posing questions, questions that may be staged inventively by artistic works and by the experimental practices of artists themselves. At the same time, social scientists involved in collaborations with artists and scientists may be burdened by expectations about their abilities to "translate" complex or abstract ideas from these experimental domains into more readily accessible forms. In the field of synthetic biology, there are strong expectations by scientific and policy-making communities and increasingly, imperatives placed on research proposals by funders, to reflect on and engage with "Responsible Research and Innovation", in order to consider the social value of scientific research, including the "engagement" of publics in the research process. These efforts are a response in part to past public controversies surrounding genetic modification and the unintended or troubling consequences of scientific innovation. The aim of these contemporary efforts to engage publics is often to involve these publics in the development of new technologies in order to explore their acceptability before they are used or brought to "market".

Calvert and Martin [5] posit two different roles for social scientists, artists and others working with synthetic biologists. The first situates the social scientists and other non-scientific partners or collaborators in research projects as "contributors", tasked with exploring the effects or consequences of scientific research. A contributor may assess the implications of a research tool or innovation but they consider the work of their scientist colleagues as distinct and separate from the work of social science. Underlying assumptions about the science (or the social science) underpinning the involvement of the researchers in a joint project remain fundamentally unquestioned although the social scientist might take a critical view of the effects or consequences of a piece of scientific research. The second role, however, is more fundamentally transformative of scientific and social scientific practice. In this role, Calvert and Martin [5] suggest the social scientist acts as a 
collaborator, which entails "involvement that can potentially influence the scientific knowledge" that is produced. This kind of involvement is much more difficult to achieve, requiring as it does the openness of all collaborators involved in a project to value the participation of others.

This commentary recounts a collaboration begun in 2014 between Julie Kent, a sociologist of the body and health technologies, Katy Connor, a visual and digital artist, and me, a geographer interested in the cultural and economic dimensions of new bodily technologies. In 2014, I hosted a workshop at Spike Island, an artists' studio and gallery space in Bristol, UK. The theme was Bodily Interiors and was developed from research on theorising the body's fleshy interior in cultural geography [6]. The event sought to bring together artists, designers, scientists and medical professionals interested in how the body's interior is understood not only as a space to be mapped, explored, dissected and analysed but also as a site and resource for scientific and aesthetic experimentation. Out of this workshop contacts were exchanged and then, over time-including two periods of maternity leave between us, followed up with conversation, occasional cups of coffee and tea, lunches and exchanges of emails about events - we became friends. Science is also a history of friendships [7]. Out of these intermittent but generative meetings together came ideas for several research proposals, some modest, others more ambitious in scale (and some successful, others not). Through Julie's work with BrisSynBio, our collaboration widened to include Ash Toye, a biochemist, and his laboratory.

The focus of the work in Ash's laboratory is the development of methods for culturing or growing, and eventually manufacturing at large scale, red blood cells for transfusion. Red blood cell transfusion is an important therapeutic intervention for many conditions. Some are acute conditions, such as blood loss through surgery, accident or childbirth. Other recipients of red blood cells may need frequent transfusions over the course of their lives. Conditions such as sickle-cell and thalassemia can require many blood transfusions over time and carry the risk to the recipient of the development of side effects from the difficulty of matching donor to recipient blood type. The aim of Ash's research is to explore the methods of growing cultured red blood cells (cRBCs) for patients with complex blood types that are difficult to match, eventually producing such cells in large infection-free quantities for therapy.
Over the course of 2017 and 2018, Katy carried out an artistic residency in Ash's biochemistry lab (see her commentary in this volume). At the same time, I helped Julie and her research assistant Rachel Hale carry out interviews with potential recipients of cRBCs to gather their views on the acceptability of this technology [8]. The work produced from Katy's residency suggests, as do many works of contemporary art focused on the "molecular turn" in science and specifically biology, the importance of considering bodies and body parts, not as discursive texts from which to read the inscription of social and cultural norms, but as "lively" matter and materials. The molecular bodies in Katy's artworks and indeed in the laboratory setting suggest that social scientific renderings of (human) bodies must include the complex worlds of the body's interior, its processes of growth, development, cell division and cell death, chemical reactions and molecular attractions. These new ways of presenting interior bodily processes are indebted to the scientific language of the "new biology" and its efforts to make visible and render more purposefully mutable, the "ongoing material de- and recomposition of bodies" ([9], p. 137).

Katy's artistic practice also raises questions and points to possibilities for future research that will contribute to the ongoing efforts to explore the bodily dimensions of research on blood. My aim in what follows below is to situate some of Katy's work in broader social scientific and geographical debates about bodies, materials and spatial concepts such as scale. The shifting scales of Katy's artworks generate new ways of visualising interior bodily processes and suggest new ways of making visible the micro- or cellular scale of the body. Her artistic practice opens up these new cartographies or mappings of corporeal geographies. While the visible body might seem like it is bounded by the skin and by notions of inside and outside, visualising the body's interior at the cellular level suggests other possibilities, revealing the multiple temporalities of cell growth and development within. The growth of red blood cells, their "liveliness" and development through the process of erythropoiesis and the laboratory efforts to manipulate and cultivate their development in vitro make visible the mutability of bodily processes.

Katy's artistic works and artistic practice, her exploration of stretching scale - enlarging the molecular and presenting the cellular architecture of the bone marrow/ cell scaffold - also suggest an important place for thinking about the multiple scales of red blood cell culture 
and red blood cell technology. Social scientists have argued that health and health care are increasingly molecularised, focused on manipulating and transforming bodily processes at the cellular level. At the same time, red blood cell culture, as we learned through our work with biochemists seeking to develop means of mass manufacturing red blood cells, is involved in commercial efforts to "scale up" production of cRBCs. cRBC researchers cite "dwindling" numbers of donors and increasing demand for blood products as well as the potential for capturing a global market for red blood cells for transfusion: "In the future cell lines produced under optimized GMP [good manufacturing practice] conditions could potentially provide a source of red cells for transfusion in areas of the world where blood supplies are inadequate or unsafe" [10]. While at its early stages, this research suggests the possibility of an altogether different structure to the existing blood economy of donors and recipients, in which commercial blood manufacturers may seek to play a key role.

These questions of scale also speak to geographical concerns for how scale as a concept has long been commonly understood as hierarchical, implying in the sphere of politics, for example, that the "big" global issues (of environmental change, of political economy, and so on) are often deemed more important than the "small" events and moments of everyday life. Rejecting this characterisation of scale as hierarchical, recent efforts to rethink scale have explored the possibility of the "site" [11] as a way to collapse this hierarchy and think otherwise about how molecular health technologies are also connected to wider dynamics in the biotech and blood economies. This speaks directly to how Katy's artworks, in exploring and exploding our presumptions of bodily scale, open up the possibility of new ways of visualising bodies in the blood economy and new ways of engaging a health technology's "publics" (including scientists, donors and patients).

\section{Nano-ethics in Artist Research: Tiny Instances in Posthuman Conduct (by Katy Connor)}

"It is no longer clear who makes and who is made in the relation between human and machine". ([12], p. 177).
In the fields of biotechnology, synthetic biology and regenerative medicine, material laboratory-based practices frame the body as bio-matter-as material for manipulation, manufacture and fabrication. There is an instrumental technics at play; here, life itself is enframed as something to be manipulated, often within an engineering paradigm. Might these narratives dismiss therefore the experiential, phenomenological body? This essay will discuss three works that originate in an artist residency, situated in a biomedical research laboratory, drawing attention to materials and media technologies used in both scientific and artistic practice.

Throughout this piece, I argue that the consideration of human bio-matter as an art medium opens up an intriguing cultural space to critically reflect upon relationships between biology and technology, materiality and ethics, as well as the production of new cultural meanings through metaphor. Artist research offers a means of revealing and articulating ways of engaging with technologies, negotiating the effects on bodies experienced "through socially inflected technologies of reproduction, communication and medical intervention" ([13], p. 41). As such, artistic practice as research contributes to modes of knowledge making, to epistemic enquiry. It is in this area, this vital and contemporary context, in which the methodology of artistic research can have real value.

My work asks therefore how we might start to consider bodies as becoming fabricated or synthetic within these scenarios as I look for slippages between a technoscientific and sensorial approach. This is what artistic practice can reveal: the gaps, the unsaid, the unforeseen. As Henk Borgdorff reminds us, the value of artist research lies "in its ability to offer the very reflection on who we are and where we stand that is obscured from sight by the discursive and conceptual procedures of scientific rationality" ([14], p. 50).

Since early 2017, I have been artist in residence at BrisSynBio. This residency has enabled me to experience first-hand the laboratory practice of cell culture and in particular that of human red blood cells: erythropoiesis. Cell and tissue culture have become ubiquitous aspects of international biotechnological research practices, where cells are bathed in a culture medium containing essential nutrients and energy sources necessary for their survival and growth outside the body, in vitro.

At BrisSynBio, scientists are developing and manufacturing human red blood cells as product in vitro, testing novel applications of product through 
pharmaceutical delivery and conducting clinical trials in cultured red blood cells in vivo. My artist research, primarily experiential, explores social and cultural aspects of this biomedical practice and through making, explores new metaphors for how we might conceive of the body in these emerging scenarios. To date, I have instigated a number of activities, which include:

- recording the performative approaches taken by staff, to working with fluids, in micro-controlled environments and wet labs

- capturing images of the cultured red cells, grown in large flasks of iridescent liquid media, using technologies: photography and video, optical microscopes, fluorescent imaging and data visualisation (flow-cytometry)

- visiting the Blood and Transplant Unit in Filton, the largest blood processing plant in Europe: one of only five centres in the UK for handling, testing and processing NHS donated blood products

- initiating conversations with scientists, discussing their work with them and reflecting on practice

- making art works that respond to the residency, laboratory culture and growth of "synthetic" blood cells: particularly in relation to their large-scale manufacture

Throughout my work, there is the constant recurrence of the body: figuratively, as a measure of scale, experientially as a sensory apparatus; and conceptually as media - as a material source for the work. The works discussed below consider the presence of these multiple bodies within the laboratory and the material translation of the corporeal through biomedical practices of computational microscopy, 3D print and large-scale cell manufacture.

One of the earliest contemporary artworks that opens this intriguing space between biology, materiality and ethics is Blood of a Poet Box (1965-1968) by Eleanor Antin. This work consists of a wooden case of glass slides, each one smeared with the blood of an artist, poet or writer. Its title is a reference to the film of Jean Cocteau, Blood of a Poet (1930). Over a period of three years, between 1965 and 1968, Antin attended art events and poetry readings in her native New York where she approached select artists to donate a pinprick specimen of blood, one for each glass slide. Antin gathered samples from avant-garde poets including Allen Ginsberg, Carolee Schneemann, Yvonne Rainer and Allan Kaprow [15]. In Blood of a Poet Box, the blood smeared onto each slide stands for the fleshy, human body as corporeal substance. Each has the implication of a scientific scrutiny: a smear is a sample of tissue or other material taken from the body and spread thinly on a microscope slide for examination, typical for medical diagnosis. These boxes are still used within laboratory practice today, as archives of biological samples: glass slides to be examined under the microscope, although they are now made of plastic rather than wood.

Here blood is both corpus and material: the oxygenating fluid circulating in the body contains a wealth of information, including blood type, genetic identity and the materials for DNA mapping and cloning. In the information age, blood can be read and processed as data: seen in terms of its availability, as information. But who owns this information? Blood of a Poet Box is Antin's artwork, but each slide is labelled with the name of the individual who donated their blood to the project, and the work exists as a rich repository of artists, poets and writers. By contrast, in the laboratory, the flasks of blood and cultured specimens are labelled with the name of the scientists who are using them in their research. They become the property of the lab.

It is this subtle distinction in approach-the ability to name, to acquire, to possess - that is of key significance in considering the way in which bodily materials are appropriated and used in the fields of biotechnology, as distinct from art and life. Here the body can be understood as multiple: both as lived experiential being and as bio-matter-material used in practices of biotechnological research and the pharmaceutical industries in their pursuit of biological patents and profit. Artist research like Blood of a Poet Box can draw attention to the ethics of such practices. In the UK, permission is still required from each donor before a scientist can use such biological material in their research: ethical consent is thus sought and approved. However, in the USA, this no longer applies. In 1990, the Supreme Court in the US State of California decreed that humans have no claim to their biomaterials as property once they leave the body. This legal precedent prevents all patients and living relatives from sharing in any profits earned from commercial products or research derived from their cells [16]. In a fluctuating political and capitalist climate, therefore, the material 
biology of the body becomes a potent and potential economic resource - open to industrial specialisations in bioinformatics, synthetic biology and pharmaceutical research.

The practice of cell culture was first developed using cancerous cells taken from Henrietta Lacks in the early 1950s. Named HE-LA after an abbreviation of their donor's name, they were cultured in vitro to become the first "immortal" cell line. However, the circumstances of her donation and her family's subsequent treatment, neglect and abuse by the medical establishment have only recently been documented [17]. Such practices reveal a critical power dynamic at the heart of biomedical technologies; the right to ownership, particularly in regard to the body's materials once they leave the confines of the human, the envelope of the skin.

Christine Borland's installation HeLa (2000) is one of the earliest artworks to consider HeLa cells as pervasive, yet undocumented materials in practices of biotechnological research. While resident artist in a biomedical laboratory in Dundee, Borland realised that many of the scientists simply had no knowledge of their material lineage or history, and she draws attention to this analytical distance in the work: the cells can be observed only via a microscope, connected to a television monitor that displays their magnified images onscreen. The audience see the HeLa cells through multiple layers of mediation.

In 2017, just prior to initiating my residency, Bristol University published research demonstrating a new "immortal" cell line [9]. Named BELA (Bristol Ethyroid Line Adult), this now provides a continuous supply of red blood cells for experimental laboratory practice, including gene-editing using CRISPR cas-9 to remove key antigens, thus making blood more "bio-compatible" [18]. Other practices include the "scaling-up" of blood manufacture: producing vast quantities of red blood cells through the culture of haemopoeitic stem cells derived from adult donated blood, in order to conduct human clinical trials timetabled to start in $2020 .^{4}$

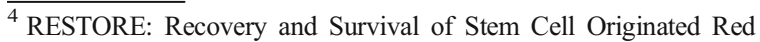
Cells. Randomised controlled phase I cross-over trial. Chief Investigator Dr. Cedric Ghevaert. Primary Sponsor NHSBT https://beta.nhsbt. nhs.uk/clinical-trials-unit/current-trials-and-studies/restore/ (last accessed 30/01/2020)
}

During my residency, I spent time in the biomedical laboratory, standing, sensing and observing the tiny movements of these cultivated red blood cells in their large glass flasks of iridescent liquid: scarlet, claret, carmine, crimson and cardinal hues, all infused with a golden shimmer. Prior to developing my art practice, I worked in media and film production, and this experience continues to inform my artist research. Here, I was struck by the similarities and interferences between the two forms of media cultures: those of the biological and those of the televisual. My emerging body of work in this field draws a parallel therefore between the growth medium in which blood cells are cultured in the laboratory and the media of broadcast technologies: between RPMI medium and contemporary televisual culture: between the transmission of data and the transmission of disease. This position resonates with anthropologist Hannah Landecker, for whom cell cultures have become "technologies of living substance" [19].

Technologies within the laboratory are designed by scientists to enable them to see particular microscopic features of the cells, their behaviour, their movements. Phase contrast microscopes specifically probe beyond the glossy, red reflective surfaces to image the cells in high contrast, black and white. In this instance, the phenomenon of colour is discarded, perceived as too distracting, too elusive for the study. The scientists are trained to look at the cells, their behaviour, conduct and equipment reinforces this technologised view of the world: their techné.

In Nature of Transmission (2017) (Fig. 2), these monochromatic video loops are played into old Black and White television sets. Here the cells become reconstituted, embodied in new host bodies or vessels. Under glass, these lively microscopic movements become televised events, the TVs providing a further technologised body for the cells, as they play out their remote adventures, outside the human.

In 1963, the artist Nam June Paik described the emergent spectacle of Television as contemporary nature "not because it changes beautifully-but that it simply changes" [20]. This overlap between biological life and the technologically "live" was a continual theme throughout Paik's work, where he articulates the viewer's corporeal involvement in an ever-present flow of signals. My sculptures allude to the simultaneous arrival of televisual culture and biological cell culture in the mid-20th century and 


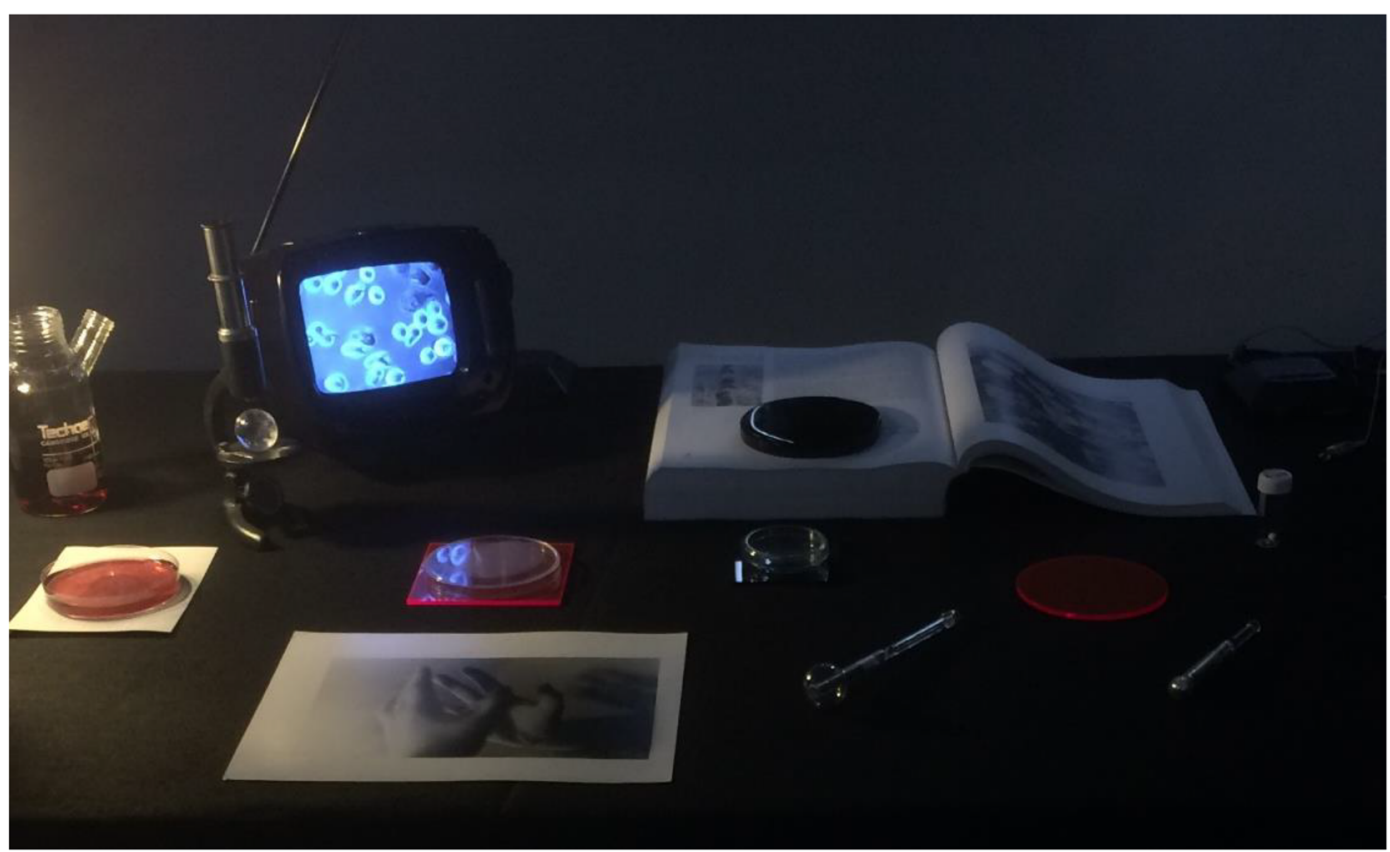

Fig. 2 Nature of Transmission (2017). Black and white TV sculpture. Presented as part of the installation Blood Culture, Konteksty, Sokołowsko, Poland (2017). Copyright the author/artist

their subsequent simultaneous proliferation throughout domestic space. These Bakelite boxes, wrapped around alien movements on-screen, are objects belonging to a different time frame: reminders of a past era of 1950s science fiction: once seen on TV, now a reality.

The colour photographs in Fig. 3 draw parallels between the slippery media of digital video production and the phenol red medium of tissue culture, making media apparent: visible to the naked eye. Through capturing moiré patterns, the photographs capture synthetic interferences, blurring any distinction between the natural and technological. In this project, biomedia is both complex and hybrid, fluid and process, simultaneously biological, social, cultural, economic and technical.

The work is a starting point for thinking about material confluences between biomedia, transmissions of data/disease and emergent technological practices. After Eugene Thacker, the biological and the digital domains "are seen to inhere in each other [...] biomedia establishes more complex, more ambivalent relations than those enframed by technological-determinist views" ([21], p. 7). Both works initiate links between the shifting luminous membrane that slips easily between the screens of electronic devices, with the iridescent media of the wet lab. The hypnotic, pulsatile beat of the televisual with the microscopic movements of the cultured cell: mediatic atmospheres increasingly absorbed into the body's rhythm and pulses.

Visual culture is often used instrumentally by science, both as a tool to visualise and illustrate scientific practice and for imaginative means of engaging the public. What are not so commonly discussed, however, are the metaphors that surround emerging technoscientific models of practice. Using nanotech as a specific example, Katherine Hayles states that "science fiction remains essential to nanotechnology precisely because it is not yet clear when and how the technology will become actualized", and yet "the choice of metaphor is consequential, for it lays down a linguistic track that thought tends to follow and suggests connections that bind new ideas into networks of existing conceptual structures" ([22], pp. 13-14).

The cultural imaginary fulfils a need for the emerging product: to provide possibilities and expand their market reach, relevance and economic viability to potential recipients and beneficiaries. Employing imaginative scenarios and often fantastical hype: "imagination is a social practice deployed in the production of science and technology. Creating future imaginaries is a major part of scientists' work in the new biotechnologies" ([23], p. 176).

The role of both linguistic and visual metaphors in the slippery spaces between culture, science and 

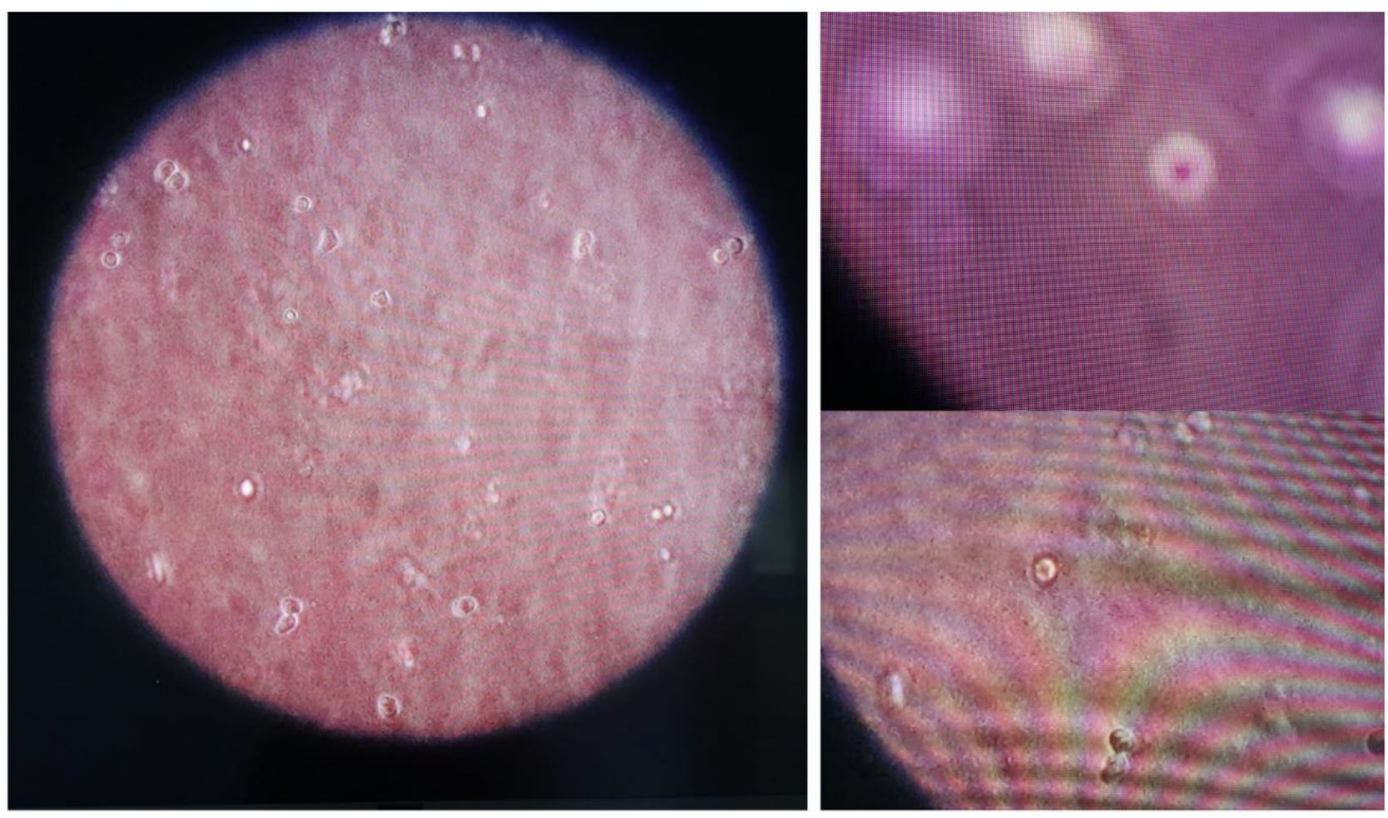

Fig. 3 Digital photographs of manufactured red blood cells suspended in video culture (2018). Copyright the author/artist

technology is of paramount importance therefore, particularly for art science collaborations. Here, metaphors operate both to concretise thinking and to open it up: to contest dominant ideologies by bringing together other approaches, stories and associations and reveal the complex issues at the heart of life manipulation.

Art Science pioneers Oron Catts and Ionat Zurr argue that the role of experiential knowledge for artists is significant. Time spent in the laboratory, understanding and practicing cell culture can enable the artist to perceive and critique the dominant metaphors and ways of conceptualising life that science promotes: "the ethical, cultural and political importance of experiential engagement with life manipulation ... can be an effective methodology to confront the complexities and to contest dominant ideologies regarding the life sciences" ([24], p. 126).

In my experience gained from the residency, the cultured red blood cells are often described using anthropomorphic terms. The scientists I spoke with used terms such as happy and lively to describe how these cells are living in their flask cultures. In vitro flasks of media and bioreactors, billions of these cells are meticulously grown, studied and analysed. This tendency to anthropomorphise cell culture has been noted by Catts and Zurr, who state that "what is unique to the dominant metaphors developing in cell biology is that they ... tend to become anthropomorphic in their individual and communal 'behaviour'” ([24], p. 138).

One of the laboratory practices I observed includes growing stem cells within a series of three dimensional scaffold structures that serve as an analogue of bone marrow [25]. Produced from a polymer foam, these tiny synthetic specimens each measure $5 \mathrm{~mm}$ cubed. Within these cubes, millions of stem cells are cultured in rich growth media. According to the scientists, these cells are happiest when they can live inside these replicant structures; here they can differentiate freely. At this scale, the spectre of the full size human figure becomes enormous, architectural in scale.

Spending time in the laboratory studying these cells, I found myself intrigued by how it might feel to live inside these synthetic marrow structures, as microdwelling places. What might these spaces look and feel like? What might we learn from the cells themselves?

To open up and reveal these, tiny spaces required the use of microscopic methods of computed tomography or CT scanning (see Fig. 4). Through scanning a tiny sample of the scaffold, I was able to create a virtual matrix, a three-dimensional mesh.

Rendered in sintered nylon, this sculptural object is a tiny fraction of the original cube. Yet magnified from the nano-scale, it gives a real sense of the intricate dwelling spaces within (Fig. 5). My future plans include building 

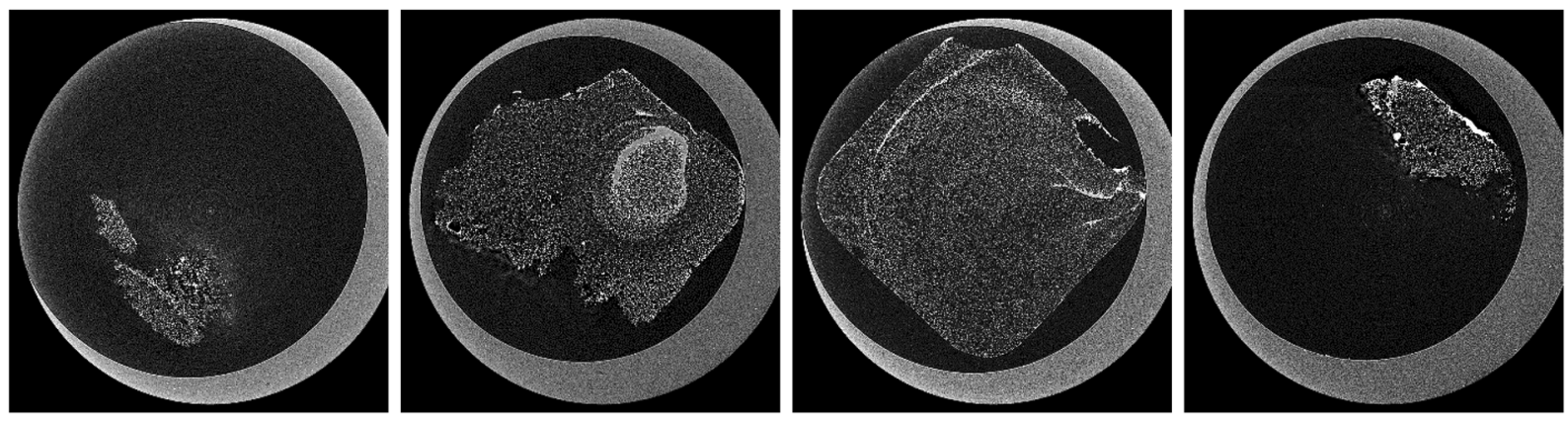

Fig. 4 Synthetic Dwelling (2018). Plans for posthuman survival: part one: replicating the bone marrow niche. Still images from micro-CT scan of synthetic bone marrow. Copyright the author/artist

this scaffold at a scale where we, as humans, can climb inside; where we can experience, kinaesthetically, the chambers of synthetic bone marrow. These works "do not simply conceptualise the volatility of existence under conditions of extreme modernity, but harness it in order to better understand it" (David Roden; from email correspondence).

By $3 \mathrm{D}$ printing the scaffold at this scale, it enables us to imagine the genesis of red blood cells within our own bodies alongside those vessels in the lab. It gives us the ability to see out from within the micro-dimension of our bodies, to imagine an interior geography where these circulating forms of red blood cells are born, develop and grow.

What does it means to dwell, to inhabit a body experientially? Is there a continual re-negotiation; an

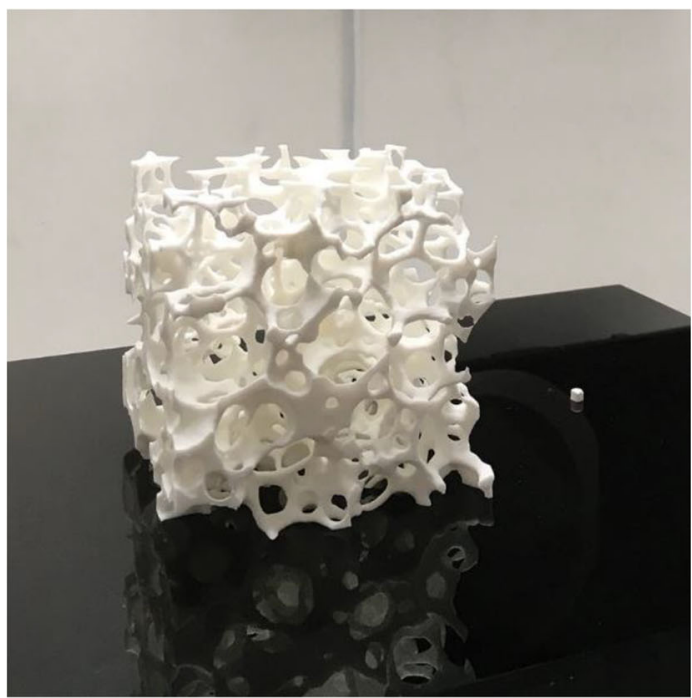

Fig. 5 Synthetic Dwelling (2018). Plans for posthuman survival: part one: replicating the bone marrow niche. Left: model of scaffold section $\left(10 \mathrm{~cm}^{3}\right)$ in $3 \mathrm{D}$ sintered nylon; synthetic scaffold (5 articulation of recurrence? In contrast to the "immortal" BEL-A cell line, unconsciously, inside our bodies, red blood cells develop, enucleate and circulate for just 120 days in their arc of life. Their unique, biconcave shape enables their continual movement through vessels and arteries, carrying oxygen in a pulsating rhythm [26].

My artist research explores these sensorial spaces: the thresholds between blood experienced as vital, living, bodily substance and blood as biotechnological product of scientific manufacture. When clinical trials start later this year, employing these laboratory-cultured or manufactured red blood cells - how might we start to consider these spaces within the sensorial biotechnological body? Are these cells fabricated? Engineered? How do we see and experience the body through the lens of synthetic fabrication?

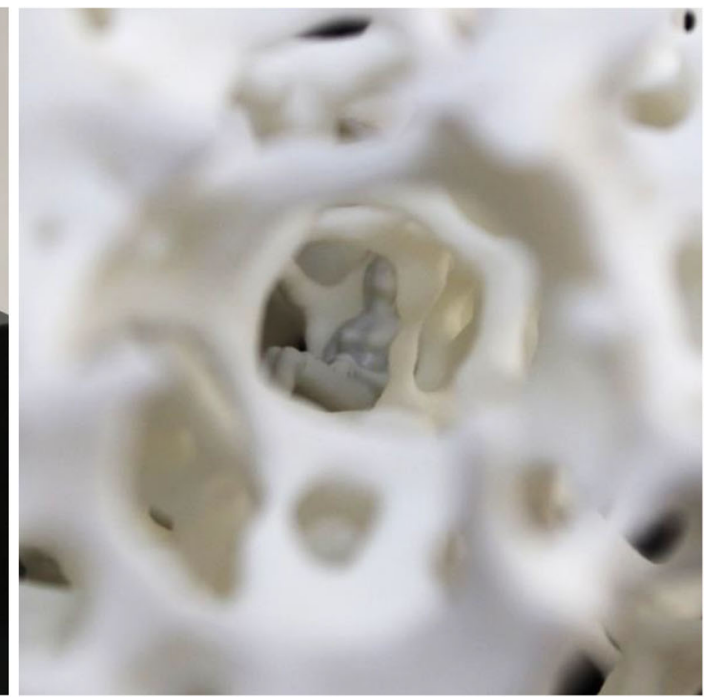

$\mathrm{mm}^{3}$ ); black glass. Right: scaffold model with architectural model (scale 1:50). Copyright the author/artist 
Here in this intimate distance, our bodies delicately negotiate this borderline between the biological, cultural, material and technological, as "political, theoretical and technological changes intersect to produce new knowledges and understandings" ([27], p. 9). Artist research becomes a vital space therefore, in which to negotiate this ethical relation, between the human and posthuman.

\section{Disappearance and Assembly (by David Roden)}

It is easy to believe nobody built this degradable substrate with that small figurine encysted within, an unsung astronaut, that the condition did not apply or that the machine "so disconnected ... never got the message". The pseudo bone increments again. She ascends, follows the hooded figure with the poppy along a drive winding towards the slender palms and their ablated sky but turns aside to see where the steps lead. She sleeps through successive revolutions - a component newly introduced to this circuit (Fig. 6).

So, although ample, the space is not a dwelling. Low artificial light is conducive to filtering such noise as might afflict us from within or without. In the Salon Carré, paintings were stacked regardless of genre. Dogs counted among the sensitive in the democracy of the Enlightenment. The floor, ceiling and walls are stark and capacious. Everything is hollowing out its place. There's a buzzing — “a dull roar like falls ... in the skull". 6

Conventions are there to be disregarded, much as the inanimate props and backgrounds of the theatre. The steeds on which the Picador or Ceaser make their entrances are living; but only the speaker has a placeeven if, like Hamlet or Beckett's motoric mouth, it vests a power of impersonal negation. Not I.

I should feel paralysis. I should not be screaming like this.

White purifies or effaces process; not simply the one who sees. The work was for itself. It lived more than the horse, more than anyone. We gathered at its edges like flies. Each look renewed us; a step taken along a path we could not know ... Another fallen key (Fig. 7).

I no longer know how to do it - to look and to forget. You are not here. Will you arrive some day? I have every

\footnotetext{
${ }^{5}$ Samuel Beckett, 'Not I', in Collected Shorter Plays of Samuel Beckett (London: Faber and Faber 1984), 218.

${ }^{6}$ Ibid. 218.
}

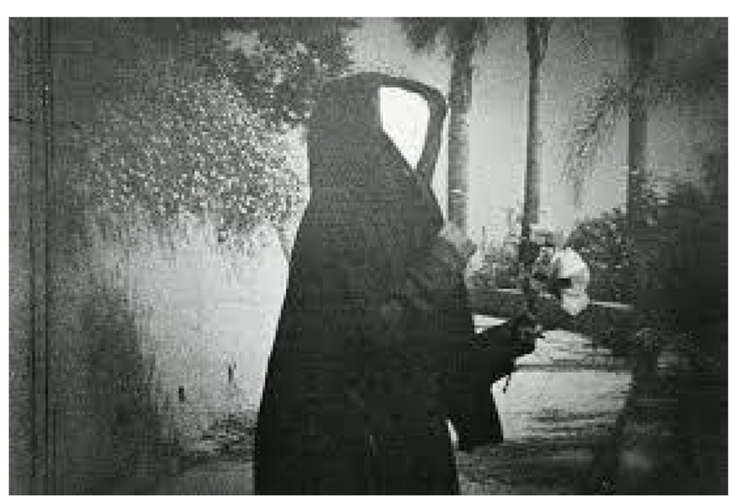

Fig. 6 Maya Deren and Alexander Hammid, Meshes of the Afternoon (1943)

reason to doubt it. Later, we toast your disappearance as a sublime tactic. Let us say that I did not search. I participated, inspiraling. You think that image is fanciful? I have been here for as long as I can recall. The space murmurs, billows; collapses outward.

What, if anything, limits or bounds if frame is so animate in form? ${ }^{7}$ I think of the curiously seductive veil worn by Cranach's Lucretia for her suicide. ${ }^{8}$ We must call to order, forget and be forgotten. The entire disposition of the gallery: Do not take photographs. Do be quiet. Cézanne's prominent delineation expects something while it is re-used, nested. Seething exoskeletal dolling-up. Cage's 4'33"' sacrificed in echoes, coughing, silence. Beyond: Nature fibrillates like a bird in a killing jar.

Whitelaw says they removed the bulbs from the exit lights in the Royal Court, leaving the audience and a figure on an invisible platform- "sex undeterminable, enveloped from head to foot in loose black djebella, with hood". 9 The observer is finally alone. The relentless mouth agape in black yoke.

The frame gives us the knot. The inside amputates history with itself; with its impossible promise.

Greenlit afternoon. Nothing to the cultivated and protected, they were piled up; abstruse rugs, pearled with cosmetic keratosis; fragrant teratomas on their presacral areas. The sky became greasy. They lined the roads. The dogs here are terrified of their handlers. We

\footnotetext{
${ }^{7}$ Immanuel Kant, The Critique of Judgement (trans. James Creed Meredith; Oxford: Oxford University Press, 1991), §14, 226.

8 Jacques Derrida, 'Parergon', in The Truth in Painting (trans. Geoff Bennington and Ian McLeod; Chaicago and London: The University of Chicago, 1987), 57.

${ }^{9}$ Samuel Beckett, 'Not I', in Collected Shorter Plays of Samuel Beckett (London: Faber and Faber, 1984), 216.
} 


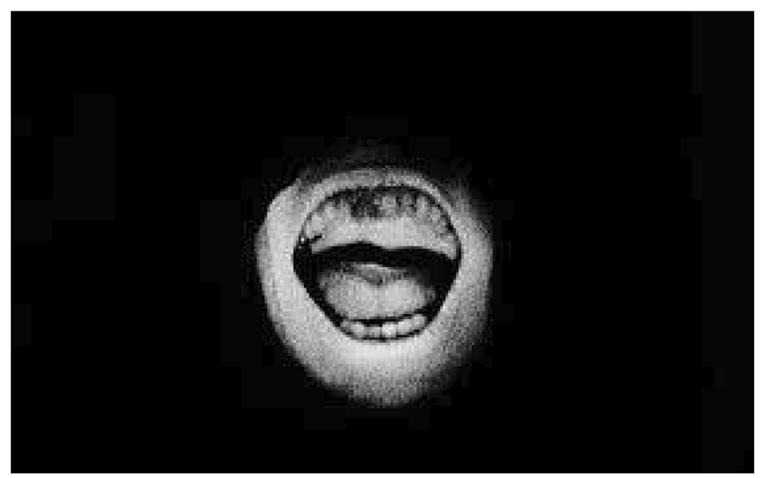

Fig. 7 Samuel Beckett, Not I (Billie Whitelaw as 'Mouth') Royal Court Theatre, London (1973)

are more malleable and less exacting than we pretend. Perhaps it is why we tamely accept her repeat, past three upstanding palms and their thin sky; through the door, behind which she waits to bleed into another (Fig. 8).

Untitled Force (2011): datasets from a nanoscale analysis of your blood assemble ridges through oceans of noise. Microscape or macroscape? The formative imagination falters with starry gulfs, violent storms or coruscating glaciers. Yet, we are reassured; imagination is victorious in defeat; its humiliation implicating, if not presenting, the supersensible, an infinite or moral "kingdom". ${ }^{10}$ Devices like this app, this Acheulian hand axe, this atomic force microscope, typify a web of in-order-to's fixed or unfixed and ultimately in our hands. ${ }^{11}$ But the Mesh is not us. We err, ramify and cruise it. We make incompatibilities and blowbacks and portals to the future. We make it go blind.

There is no defeat or transcendence, no here here. Nothing springs up poetically or in shattering pain. It is the Outside frame or hand. This network cannot be reduced to its nodes. Even its appearance smiles without defeat.

At the Lab, they complained that managing data from the Atomic Force Scans of blood strained the bounds of

\footnotetext{
$\overline{10}$ '[W]ho would want to call sublime such things as shapeless mountain masses piled on one another in wild disarray, with their pyramids of ice, or the gloomy raging sea? But the mind feels elevated in its own judgment of itself when it contemplates these without concern for their form and abandons itself to the imagination and to a reason that has come to be connected with it - though quite without a determinate purpose, and merely expanding it-and finds all the might of the imagination still inadequate to reason's ideas.' Kant, Critique of Judgement, $\S 26,255$.

${ }^{11}$ Peter-Paul Verbeek, What Things Do: Philosophical Reflections on Technology, Agency, and Design (University Park PA.: Penn State Press 2005), 117.
}

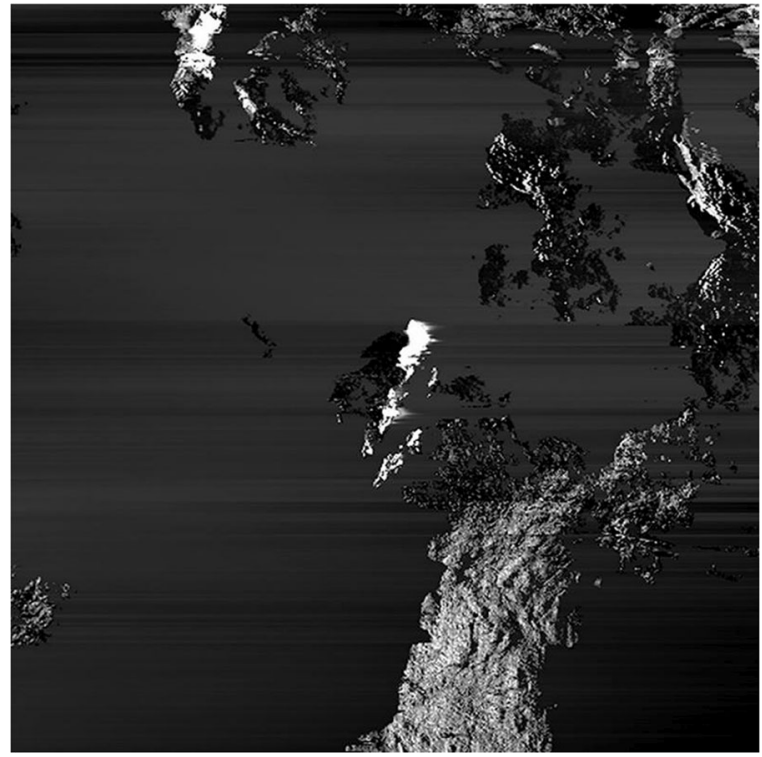

Fig. 8 Katy Connor, Untitled Force (2011) Atomic Force Microscope scan of the artist's blood. Copyright the author/artist

efficient computation (short of actual intractability obviously). It was artful to juxtapose this virtual territory with Friedrich's Das Eismeer: white thermoplastic fracturing under the hood of an industrial 3D printer (Fig. 9).

Synthetic biology instantiates and exploits functional indeterminacy locally, like any technology: introducing heterologous elements to rationalise and "refactor" genetic networks, replacing redundant DNA to make up a cleaner control surface.

Ramifying networks - organisations, cities, roads, communication grids - ceased to have any part of us. We're in the bone yard of noncompliance. Bodies become blanks, templates or platforms. ${ }^{12}$ Their counterfinality is the faint buzzing between stars. Cellular noise pre-empts any partition into abstract possibility spaces. ${ }^{13}$ There is no end to this and no Idea or Kingdom pays us off. History was evacuated. I have worked to bury this tight. Did you miss it? An anorganic howl bakes up the shingle (Fig. 10).

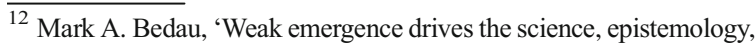
and metaphysics of synthetic biology', Biological Theory 8, no. 4 (2013): p. 338.

${ }^{13}$ Barbara Bravi and Giuseppe Longo, 'The unconventionality of nature: biology, from noise to functional randomness', in International Conference on Unconventional Computation and Natural Computation. (ed. by Ian McQuillan and Shinnosuke Seki;Cham: Springer, 2015), 16.
} 


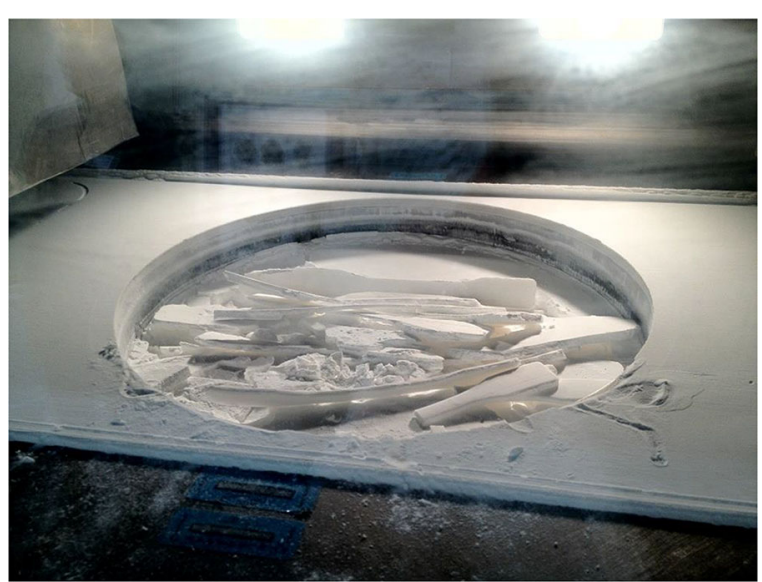

Fig. 9 Katy Connor, Das Eismeer (2012) Copyright the author/artist

Pure Flow (2009) allegorizes the Outside where drones and biosensors survey and unpeople borders. Perhaps the hocketing noise from data passing between a GPS and its proprietary satellites traces the lapse between infrastructure and frame. This network revelling in dubious and pointless miracles: as if the Matador's bursting eye lactates between the world and a black universe. ${ }^{14}$ What happens when the Mesh distends and flows; what does it mean to use Flow as a mobile app? In reaction, we dream of something we might share. And perhaps secretly hope it will be reasonable to succumb to the desert or the flood; or not objectionable. It is only death.

Perhaps I feel nostalgic for that old futurity, its innumerable repetitions and stillnessness. If it had all suffused us with impossible light one day, its prolepsis would have been infinite. They listen to Miles coil around Evans' modal voicings. Their sensations senseless in all the best ways; lost "between an already determined past and a deadend future". ${ }^{15}$ The network, meanwhile, is mycelial, vascularising. We fail to see where the frames and heuristics are no better than random. It recalls the incoherent multiplicity of the cephalopod as it circles in a way we cannot feel, anticipate or abandon on principled grounds. ${ }^{16} \mathrm{My}$ dream is to recognize the cloaked and hooded one and give her a name. Only, it is not us. I saw the first critical body between the exhibits, dripping with blood or some new

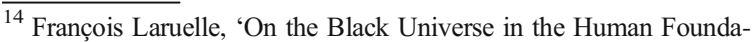
tions of Colour', in From Decision to Heresy: Experiments in NonStandard Thought (Falmouth: Urbanomic, 2012), 401-408.

${ }^{15}$ Gilles Deleuze, Cinema II: the Time-Image (London: Bloomsbury Publishing, 2013), 24.

${ }^{16}$ Eugene Thacker, Tentacles Longer Than Night: Horror of Philosophy (Vol. 3) (Alresford: John Hunt Publishing, 2015), pp. 149, 172-4.
}

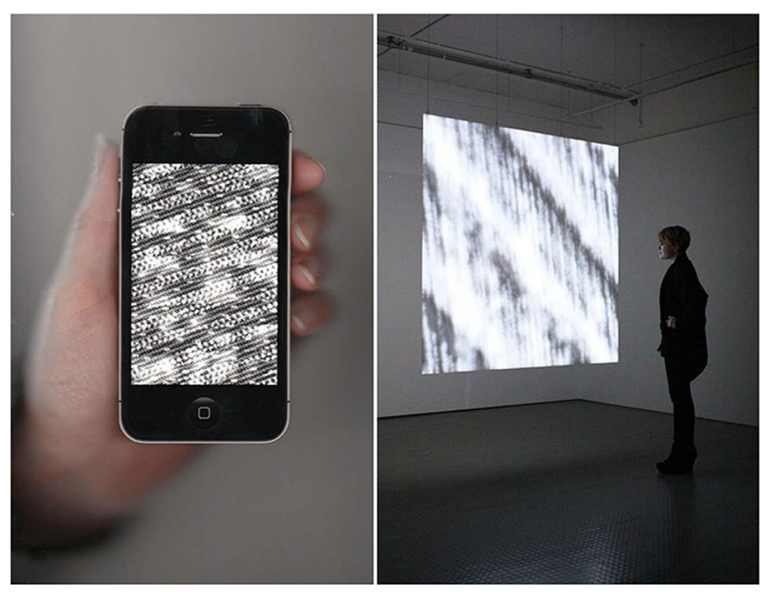

Fig. 10 Katy Connor, Pure Flow $(2009,2011)$ Copyright the author/artist

transport mechanism: anterior stubs approximate a face, perhaps a stomach, boneless limbs sketched along an axis.

In your Synthetic Dwelling (2018), part of a polyHIPE matrix for culturing blood cells in an environment designed to "mimic bone marrow" has been $3 \mathrm{D}$ printed from data derived from a CT scan. It is white, $10 \mathrm{~cm}$ cubed, peppered with voids; passages, some thousands of times larger than the original. That is tiny: like a flake of aspirin with thousands of connected micropores. The sculpture beside it remains anonymous; a map of large-scale cosmological structure; one of Jack Kirby's energy pulses roiling black with negation.

Can anybody claim to know what is here; what is missing? The space you render inscribes what cannot appear and asks whether it belongs to us. Which makes me wonder: is the Synthetic Dwelling in its place? Perhaps this also is a machine for calcifying purpose, a construction of local activators and repressors built to archaic instructional loops. Unlike the discrete modernist cells of Warhol's Marylyn Diptych, or set theory, these whorls permit growth, the extension of larger tissue (or the death of affect and the libertinage of Reason). It is only notionally a "representation" or sculpture. Where have we seen that it 'is' the matrix? Not on its plinth-though you have helpfully juxtaposed it with the original. We cannot. We trust you or another to have observed the shared pocketing through a microscope.

The video animation is based on CT scan data whose time series furnished the "bone seed". It is waiting for no one. I think of the white choirs burgeoning into a Cathedral on a dead rock, out on the edge of a sterile galaxy. It would operate perfectly there. It is not for us, or for you, or for art. That is also local and temporary. This critical body was 
never alive. It writes though it never lived. It will survive through the centuries to come. The tools were co-opted and have nothing to do with us. Without frame and thus form. You told us what the PHP scaffold was for before it became a metaphor for something else. Do we still know what it is, outside the place where the blood cells are fashioned (Fig. 11)?

We are told, to the contrary, that the aim of synthetic biology is "rational engineering": the production of biological systems that do not currently exist or the reengineering of existent systems. There are two complications: that engineered biological systems will exhibit emergent, context-sensitive properties that can only be discovered through crawling the causal meshes ${ }^{17}$; and that these contexts are, in any case, technological, prone to self-catalysing, exogenous noise. As if in confirmation, you tell me that you have other plans, to build a larger "exploratory play space" into which we will climb like bloodsuckers, memorializing our status as obligatory components in all this. There's a kind of pathos here, though there is nothing collective about this effort. The network ramifies and coruscates unpredictably. The black motormouth cannot see - that is for the one Beckett calls the "auditor" and there will be nothing for him, either; though it will eventually happen. The modern eliminates itself-in which case it is not - or it survives, tormented by its impossibility.

A digital sound sample can be thought of as a numerical list whose output depends on the order in which it is read. Read with a simple ramp function and pass through Digital/Analog converter; you get something like "playback". Read it with any other function and you get a distinct sound. It can be copied, reordered, stored in multiple locations; control other digital processes, modulate other sound sources. It is better thought as a pattern or event rather than a thing. Zero Landscape (2016) explores the implications of such patternism for our perception of real environments and bodies: contoured 3D printed nylon sculptures and 2D prints generated using geo-mapping algorithms from measurements of the Van Der Waals force between molecules of your blood.

These digital solids seem to withdraw from the viewer, as if reserving a secret that can never be made visible. As you wrote: "The image flickers between representation and digital surface; its media inseparable from its subject, rendering it hard to decipher". And the famous

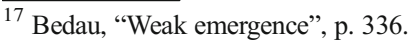

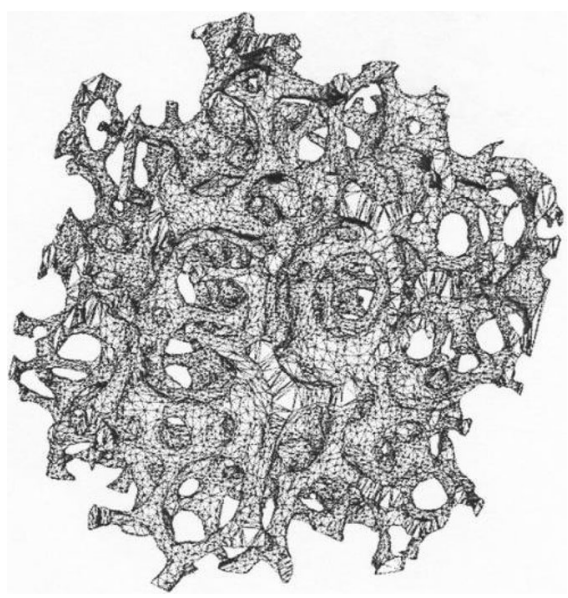

Fig. 11 Katy Connor, Pure Flow $(2009,2011)$ Copyright the author/artist

apophasis of desert theologians allows us to approach the empty time of the Mesh. And I suppose this withdrawal delivers us even from the myth of the hooded observers, frame and work. Not We. Where beauty and frame imply the possibility of cognition, your thing is unhinged. We cannot find it in the mechanisms of the gallery - the poorest, least terrifying enemy of purpose. So, if we do not know what to look for, perhaps you should come back. Please advise us.

But you are not here. Perhaps the scientists will oblige. There is no convention to determine how we must enjoy a beach, a waterfall, or a fossil. We learn such by attending to their generative mechanisms. ${ }^{18}$ But these productions are neither natural nor conventional; nor representations of anything. Did you bleed out on the Zero Scarp? The line between North and South, the dead places where the migrations stopped. The first and final sign. And here you recall Deren, winding up by the lengthening shadows; falling, like us, into the depths of the Mesh; seeing the hooded one look back on the few occasions she looks. Zero or the Null gives it back. The Gallery falls quietly into dust or it is extending, replicating, deframing everywhere. It is why you cannot come here. Everything operates but nothing works. They fill it from without, like grafts or grifters.

Acknowledgements Funding for Katy Connor's artist residency came from the Brigstow Institute and BrisSynBio (Bristol BioDesign Institute), University of Bristol, UK. The authors would like to thank Professor Julie Kent (UWE, Bristol emeritus)

\footnotetext{
${ }_{18}$ Allen Carlson, 'Nature, aesthetic judgment, and objectivity', The Journal of Aesthetics and Art Criticism 40, no. 1 (1981): 15-27.
} 
and Dr. Ash Toye (University of Bristol). Darian Meacham was partially funded by BrisSynBio.

Open Access This article is licensed under a Creative Commons Attribution 4.0 International License, which permits use, sharing, adaptation, distribution and reproduction in any medium or format, as long as you give appropriate credit to the original author(s) and the source, provide a link to the Creative Commons licence, and indicate if changes were made. The images or other third party material in this article are included in the article's Creative Commons licence, unless indicated otherwise in a credit line to the material. If material is not included in the article's Creative Commons licence and your intended use is not permitted by statutory regulation or exceeds the permitted use, you will need to obtain permission directly from the copyright holder. To view a copy of this licence, visit http://creativecommons.org/licenses/by/4.0/.

\section{References}

1. Jasanoff S (2019) Can science make sense of life. Polity Press, Cambridge

2. Reinsborough M (2020) Art-science collaboration in an EPSRC/BBSRC-funded synthetic biology UK research centre. NanoEthics (online first). https://doi.org/10.1007 /s11569-020-00367-3

3. Pansera M, Owen R, Meacham D, Kuh V (2020) The transformative challenges of responsible innovation in synthetic biology: insights from a UK multi-disciplinary research centre. Journal of Responsible Innovation (forthcoming)

4. Simons M (2020) The diversity of engineering in synthetic biology. Nanoethics. https://doi.org/10.1007/s11569-01900348-1

5. Calvert J, Martin P (2009) The role of social scientists in synthetic biology. EMBO Rep 10(3):201-204

6. Colls R, Fannin M (2013) Placental surfaces and the geographies of bodily interiors. Environ Plan A 45(5):1087-1104

7. Prochiantz A (2008) Géométries du vivant. Collège de France/Fayard, Paris

8. Hale R. Kent J (2017) 'Extending the gift'? Donor perspectives on laboratory grown red blood cells. Blood and Transplant Matters (50), p. 10-11. https://nhsbtdbe.blob. core.windows.net/umbraco-assets-corp/14976/finalversion-btm-issue-50.pdf. Accessed 6 April 2020

9. Hawkins H, Straughan ER (2014) Nano-art, dynamic matter and the sight/sound of touch. Geoforum 51:130-139

10. Trakarnsanga K, Griffiths RE, Wilson MC, Blair A, Satchwell TJ, Meinders M, Cogan N, Kupzig S, Kurita R, Nakamura Y, Toye AM (2017) An immortalized adult human erythroid line facilitates sustainable and scalable generation of functional red cells. Nat Commun 8:14750

11. Woodward K, Jones JP III, Marston SA (2010) Of eagles and flies: orientations toward the site. Area 42(3):271-280

12. Haraway D (1991) A cyborg manifesto: science, technology, and socialist-feminism in the late twentieth century. In:
Haraway D Simians, Cyborgs and women: the reinvention of nature. Free Association Books, London, pp149-182

13. Jones A (2012) Survey. In: Warr T (ed) The artist's body. Phaidon, London

14. Borgdorff $\mathrm{H}$ (2010) The production of knowledge in artistic research. In: Biggs M, Karlsson H (eds) The Routledge companion to research in the arts. Routledge, London, pp 44-63

15. Bradnock L E (2016) In focus Eleanor Antin, Blood of a poet box, 1965-68. Tate Online. eprints.nottingham.ac. $\mathrm{uk} / 35248$

16. Stevens H (2016) Biotechnology and society: an introduction. University of Chicago Press, Chicago

17. Skloot R (2010) The immortal life of Henrietta Lacks. Random House, New York

18. Hawksworth J, Satchwell TJ, Meinders M, Daniels DE, Regan F, Thornton NM, Wilson MC, Dobbe JG, Streekstra GJ, Trakarnsanga K, Heesom KJ, Anstee DJ, Frayne J, Toye AM (2018) Enhancement of red blood cell transfusion compatibility using CRISPR-mediated erythroblast gene editing. EMBO Mol Med 10(6). https://doi.org/10.15252 /emmm.201708454

19. Landecker H (2007) Culturing life: how cells became technologies. Harvard University Press, Cambridge, MA

20. Paik N J (1963). In: Youngblood G (1970) Expanded cinema. P Dutton \& Co Inc, New York, pp 302-308

21. Thacker E (2004) Biomedia: electronic mediations. University of Minnesota Press, Minneapolis

22. Hayles NK (2004) Connecting the quantum dots: nanotechscience and culture. In: Hayles NK (ed) Nanoculture: implications of the new technoscience. Intellect, Bristol, pp 11-23

23. Fujimura J (2003) Future imaginaries: genome scientists as socio-cultural entrepreneurs. In: Goodman A, Heath D, Lindee S (eds) Genetic nature/culture: anthropology and science beyond the two-culture divide. University of California Press, Berkeley, pp 176-199

24. Catts O, Zurr I (2008) The ethics of experiential engagement with the manipulation of life. In: da Costa B, Philip K (eds) Tactical biopolitics: art, activism and technoscience. MIT, Cambridge, MA

25. Severn CE, Macedo H, Eagle MJ, Rooney P, Mantalaris A, Toye AM (2016) Polyurethane scaffolds seeded with CD34+ cells maintain early stem cells whilst also facilitating prolonged egress of haematopoietic progenitors. Scientific Reports 6:32149

26. Bessis M (1974) Corpuscles: atlas of red blood cell shapes. Springer, Berlin

27. Betterton R (1996) An intimate distance: women, artists and the body. Routledge, London

Publisher's Note Springer Nature remains neutral with regard to jurisdictional claims in published maps and institutional affiliations. 